\title{
CHOLINERGIC MECHANISMS IN THE CAT VESTIBULAR SYSTEM
}

\author{
I. Matsuoka* and E. F. Dumino \\ Department of Pharmacology, University of Michigan. Ann Arbor, Michigan 48104
}

(Accepted 25 June 1974)

\begin{abstract}
Summary--A neuropharmacological study was undertaken in the cat to obtain further evidence of the role of acetylcholine in vestibular function. It was shown that the vestibular nerve contains about half or less the enzymatic activity of choline acetyltransferase. acetylcholinesterase, cholinesterase and total cholinesterase than nucleus vestibularis lateralis (NVL).

Field potentials as well as discharge of single neurones of nucleus vestibularis lateralis (NVL) were studied in locally anaesthetized. decamethonium immobilized ventilated cats before, during and after vestibular nerve and reticular formation stimulation. Various cholinergic agonists and antagonists and the adrenergic agonists L-DOPA and (+)-amphetamine were then given intravenously to determine their effects. Three major evoked potentials to vestibular nerve stimulation were recorded in NVL. These potentials were labelled $N_{1}, N_{2}$ and $N_{3}$ on the basis of polarity and latency. Although the $N_{1}$ and $N_{3}$ waves were not much affected. the $N_{2}$ wave was dramatically enhanced by physostigmine and reduced by scopolamine.

About half of NVL neurones excited by vestibular nerve stimulation responded to muscarinic cholinergic drugs. Nucleus vestibularis lateralis responses to reticular formation (RF) stimulation were primarily nicotinic and were blocked by the nicotinic antagonist, mecamylamine, but not trimethadinium. Some neurones excited by RF stimulation were enhanced by L-DOPA or $(+)$ amphetamine. The data indicate that cholinergic mechanisms are strongly involved in vestibular function. Adrenergic mechanisms are also involved, but to a much lesser extent.
\end{abstract}

It is well known that anticholinergic drugs are useful antimotion remedies. Therefore, it is pertinent to determine the role of cholinergic mechanisms in vestibular function. The known histochemical localization of acetylcholinesterase (AChE) in cat nucleus vestibularis is complex. Acetylcholinesterase levels are high in the superior and lateral nuclei, but low in the medial and inferior portions (FRIEIE, 1966). In the nucleus vestibularis lateralis (NVL) the cell bodies of Deiters' giant neurones contain almost all of the AChE. SHUTE and Lewis (1960) and Ross (1969a, b) have also shown AChE in the vestibular ganglion of Scarpa. Steiner and Weber $(1964,1965)$ and Yamamoto (1967) reported that NVL neurones activated by vestibular stimulation were also excited by the iontophoretic application of acetylcholine (ACh). Further neuropharmacological investigations on the cholinergic mechanisms in the vestibular system are obviously needed.

In this paper we describe our studies on the gross distribution of choline acetyltransferase (ChAc), AChE, cholinesterase (ChE) and total cholinesterase in the cat vestibular nerve and nucleus vestibularis lateralis (NVL). In addition, spontaneous unitary discharges were recorded in NVL neurones as well as field potentials to vestibular nerve stimulation before and after various cholinergic agonists and antagonists.

\section{METHODS}

\section{Neurochemical analysis}

Eight adult cats of either sex were used. After pentobarbital sodium $(30 \mathrm{mg} / \mathrm{kg}$ i.v.). each animal was placed in a stereotaxic instrument. In order to locate the NVL, a small electrode was inserted into the right side of the nucleus and fixed to the cranium with dental cement. The right vestibular nerve and brainstem were exposed under microscopic surgery using a Zeiss microscope (X6-X40). The vestibular nerve including Scarpa's ganglion and NVL was dissected out for chemical assay. Choline acetyltransferase was assayed radiochemically using a modification of the method of SCHRIER and SCHUSTER (1967) and

\footnotetext{
* Present address: Department of Otolaryngology, Faculty of Medicine, University of K yoto, Kyoto, Japan.
} 
MCCAMAX and Ho N 11965$)$. Tolal (hF. AChE and (hF were assalyed radiochemically using the method of SIAKATOS. FII.BIFR and HESTl:R (1969). Total protein was assayed by the method of LOWRY, Rosibror GH. FARR and RAYIMALL (1951).

\section{Nemopharmacological sudies}

Thirty-nine normal adult cats of either sex. weighing $2.54 .0 \mathrm{~kg}$. were used. All surger! wasperformed under diethylether oxygen anaesthesia. The trachea. fimoral artery and vein were cannulated. A section. aboul $8 \mathrm{~mm}$ diameter. of the mucous membrane of the middle car cavity was removed through an approach via the right lympanic hullat. A small concentric bipolar steel electrode was inserted through the round windom according to the

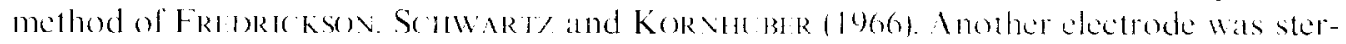
cotaxically inserted through the eerebellum into the reticular formation (RF). The recording microclectrodes were gold tipped stainless steel and tungsten wires (BOL DRIAL. BII:RIR and KalHmav. 1968: Ho B1:1. 1957: NalTo. Persontt communication). Their electrical resistance was between 0.75 and $10.0 \mathrm{M} \Omega$. With reference to a stereotavic brain atlas (SNMmR and NIr:Mr:R. 1961). the recording electrode was inserted into the right vestibular nucleus (MAISt OKA. 1967. 1969), primarily NVL. The microelectrode wals connected through a cathode follower to a Grass P-5 amplifier and the potentials displayed on a Tektronix dual beam oscilloscope. An amplitude discriminator was used to convert the action potentials into a pulse of constant amplitude and duration (T.MC. Model 605 . 606). This was fed into a (AT $400 \mathrm{~B}$ computer and data printer 1 Model $5(x) A$ ) which yielded on-line poststimulus time histograms of single unit activity.

In aach recording. 30 sweeps following stimulation or spontancous unit activity were summated on the computer. All data displayed on the oscilloseope were photographed on Kodak plus X film using a Grass recording camerat. In some calses, the data from the computer were also displayed on a dual beam oseilloseope and recorded on Polatroid film.

After all operative procedures were completed. the animal was locally andesthetied al all wound edges with 0.5 " lidocaine and then immobilised with decamethonium (1.0 $\mathrm{mg}$ $\mathrm{kg}$ per br i.v. Artificial respiration was maintained immedialts after injection of decamethonium. Body temperature was kept at 36 .38 C hy means of atn alutomatic heating pad (German Rupp Industry Ine.. Model K 1.31 . Lnder these conditions. the mean \pm S.E. values of $\mathrm{pH} . P \mathrm{O}_{2}$ and $P\left(\mathrm{O}_{2}\right.$ of arterial blood of 5 animals were as follows: $\mathrm{pH}$ $7 \cdot 37 \pm 0.005 . P O_{2}=105.01 \pm 5.7 \mathrm{~mm} \mathrm{Hg}$ and $P\left(\mathrm{O}_{2}=39 \cdot 1\right) \pm 6.0 \mathrm{~mm} \mathrm{Hg}$. These values were almost the same as normal control animals. The arterial hlood pressure was recorded by means of a strain gatuge from the femoral artery.

The right vestibular nerve and the RF were stimulated with a square wave pulse. (0). (0) msec and $0.1 \mathrm{msec}$ in width. delivered from a (jrass $S-8$ stimulator. The intensity of stimuli ranged from 1.0 to $5.0 \mathrm{~V}$. Single shock stimuli were usuall! used, but in some cases pulse trains $(50.150$ and $250 \mathrm{H} .40 \mathrm{msec}$ train duration and 11.5 msec pulse width were applied. At the end of each experiment. a $22.5 \mathrm{~V}$ dec current wats applied to the microelectrode so that the site of recording could be contirmed histologically (see fig. 1).

\section{RI:SI:ITS}

Cholinergic metrochemistry of the restibutar system

As shown in Table 1. the content of (hAc. AChl. Chl and total chl was higher in NVL than in the vestibular nerwe including Scarpa's ganglion.

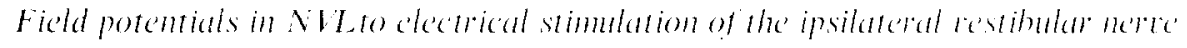

Field potentials evoked to vestibular nerve stimulation were classified as $\lambda_{1} . \wedge_{2}$ and $N_{3}$ waves. These potentials were almost the same as the $P, N_{1}$ and $N_{2}$ waves of Shimaze and Pricht (1965). The $N_{1}$ wave wals at small negative and sometimes positive potential.

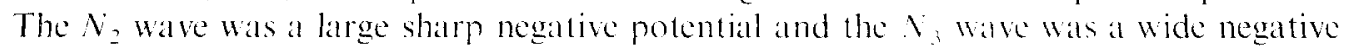
potential. The means \pm S.F. of the lateney on these three watues for seven animals were $x_{1}=0.50 \pm\left(1.03 . x_{2}=1.09+(1.0) 3\right.$. and $x_{3}=2.43 \pm(1.21$ msec. These values were almost the same as those obtained by Sumazi and PrI (1) $(1965)$. When the microelec- 
Table 1. Cholinergic neurochemistry of the cat westibular axon and nuckus vestibularis lateralis

\begin{tabular}{|c|c|c|c|c|}
\hline Assay & $n$ & Axon & $n$ & Nucleus \\
\hline ChAc & 0 & $2.78 \pm 0.77$ & 6 & $4 \cdot 30 \pm 0.65$ \\
\hline $\mathrm{AChE}$ & 2 & $78.50 \pm 43.51$ & 7 & $171.94 \pm 27.13$ \\
\hline $\mathrm{ChE}$ & 3 & $75.67 \pm 46.76$ & 7 & $280 \cdot 20=37 \cdot 04$ \\
\hline Total ChE & + & $262.90 \pm 149 \cdot 10$ & 7 & $934 \cdot 40=142 \cdot 20$ \\
\hline Protein & + & $0.75 \pm 0.15$ & 7 & $0.85 \pm 0.09$ \\
\hline
\end{tabular}

ChAc is expressed as mean $\mu$ mol ACh g per hr \pm S.E

$\mathrm{AChE}$ was measured using ${ }^{14} \mathrm{C}$-labelled methacholine. $\mathrm{ChE}$ using $\left[{ }^{1+} \mathrm{C}\right]$-butyrylcholine and total Chl: using $\left[{ }^{14} \mathrm{C}\right]$-ACh as substrates and expressed as mean $\mu$ mol g per hr. Protein is expressed as $\mathrm{mg} \mathrm{ml}$ of $\mathrm{I}^{\circ}$, homogenate.

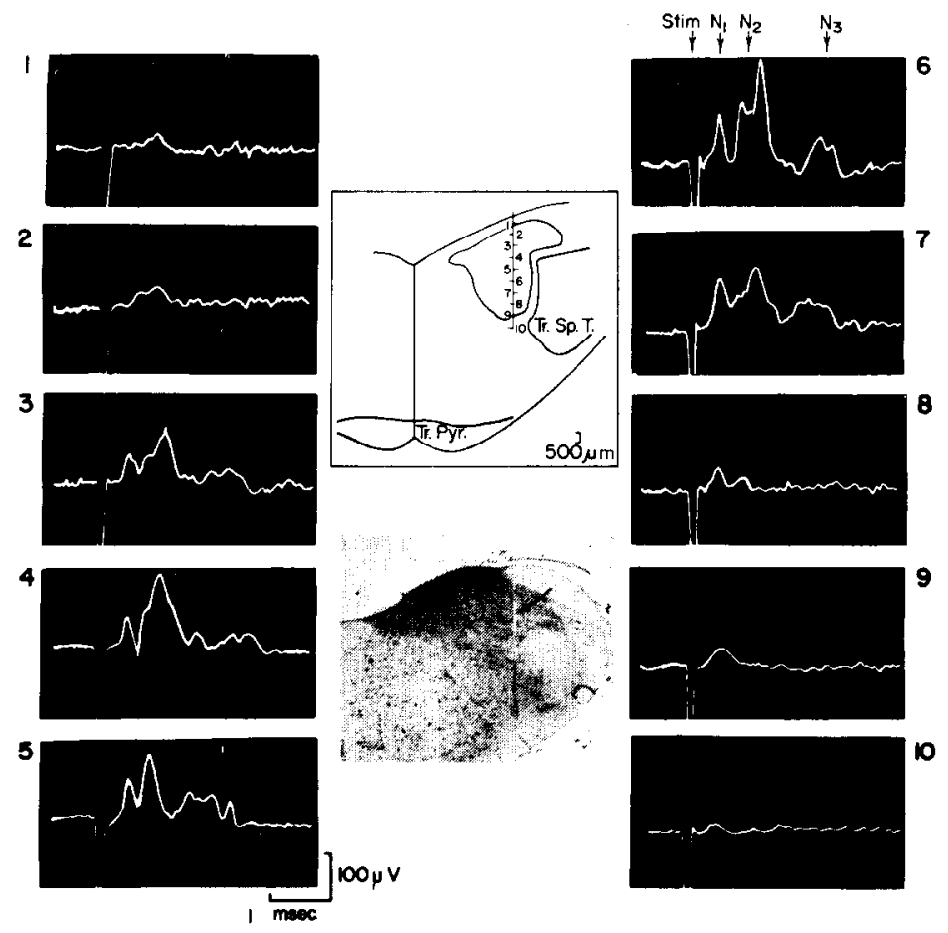

Fig. 1. Fvoked potential responses of nucless vestibularis kateralis to ipsilateral vestibular nerve stimulation. Tr. Pyr.: tractus pyramidalis: Tr. sp. T.: tractus spinalis n. trigemini. Evoked potentials at varying depths in NVL are illustrated. Note that following the stimulus artifact. prominent $N_{1}$. $N_{2}$ and $J_{3}$ waves are recorded at positions 3-7 in this nucleus. Note that the evoked potential of $N_{2}$ wave has two peaks at position 6 .

trode was inserted into NVL. a characteristic field potential was evoked by single shocks to the vestibular nerve. The typical response was always elicited in the middle portion of NVL. The $N_{2}$ wave sometimes had two or three peaks. This indicates that there are different conducting axons in the peripheral vestibular nerve. The alterations in the $N_{1}$ and $N_{2}$ waves during different placements of the microelectrode from a dorsal to a ventral trajectory are shown in Figure 1. The potentials are helpful for locating single neuronal responses to specific portions of NVL. The mean amplitudes \pm S.E. of these waves in seven animals are as follows: $N_{1}=96.7 \pm 10 \cdot 7 . N_{2}=176 \cdot 3 \pm 14.5$ and $N_{3}=123.4 \pm 17.5 \mu \mathrm{V}$. as illustrated in the bar graph in Figure 2.

\section{Effects of cholinergic agonists}

Two minutes after administration of nicotine $(25 \mu \mathrm{g} / \mathrm{kg}$ i.v. $)$. the mean amplitude of the $N_{1}$ wave was not significantly reduced $(P>0.05)$ to $73.5 \pm 10.5 \mu \mathrm{V}$. The mean amplitude of the $N_{2}$ wave was significantly reduced to $101 \cdot 2 \pm 36.1 \mu \mathrm{V}(P<0.01)$ while the amplitude of the $N_{3}$ wave did not change $(P>0.05)$. Five minutes after administration of physostigmine $\left(25 \mu \mathrm{g} / \mathrm{kg}\right.$ i.v.), the mean amplitude of the $N_{2}$ wave increased to $315 \cdot 0 \pm 29 \cdot 8 \mu \mathrm{V}$ ( $P<0.001$ ). However. the $N_{1}$ and $N_{3}$ waves did not change (Fig. 2). The accumulative 


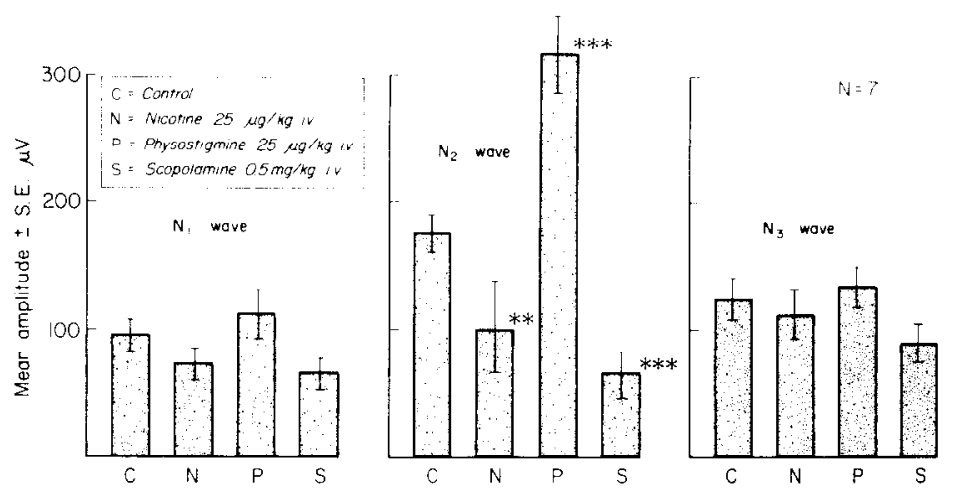

Fig. 2. Fffects of various cholinergic drugs on the amplitude of evoked nucleus vestihular is lateralis potentials clicited with single shocks to the ipsilateral vestibular nerve. Each bar height represents the mean amplitude of a specific wave as designated. Note the dramatic effects of physostigmine in facilitating the $\mathrm{N}_{2}$ wave as well as scopolamine in reducing it. This wave was reduced following nicotine. All responses were measured 5 min after drug administration except after nicotine, which wals measured 2 min after injection. ${ }^{*}=P<0.05 ; * *=P<0.01 ;^{* * *}=P<0.001$.

dose response curve of physostigmine is shown in Figure 3 . The $N_{1}$ wave was not significantly increased with intravenous doses of 25 and $50 \mu \mathrm{g} / \mathrm{kg}$. The $N_{2}$ wave was remarkably enhanced even in small doses $\left(5 \mu \mathrm{g} / \mathrm{kg}\right.$ i.v.). The $N_{3}$ wave did not change at all. The optimal intravenous dose of physostigmine which facilitated the $N_{2}$ wave was $25 \mu \mathrm{g} / \mathrm{kg}$. Larger doses caused a slight reduction.

\section{Effects of cholinergic antagonists}

As described above, the amplitude of the $N_{2}$ wave was enhanced by physostigmine in intravenous doses of $25 \mu \mathrm{g} / \mathrm{kg}$. This enhancement was reduced by scopolamine $(0.5 \mathrm{mg} / \mathrm{kg}$ i.v.). In this dose, scopolamine did not reduce the $N_{1}$ and $N_{3}$ waves. The effects of cumulalive doses of scopolamine are shown in Figure 3. The $N_{1}$ wave was also reduced by large doses of scopolamine. In contrast. the $N_{2}$ wave was markedly reduced. even with small doses of scopolamine $(0 \cdot 25 \mathrm{mg} / \mathrm{kg}$ i.v. $)$.

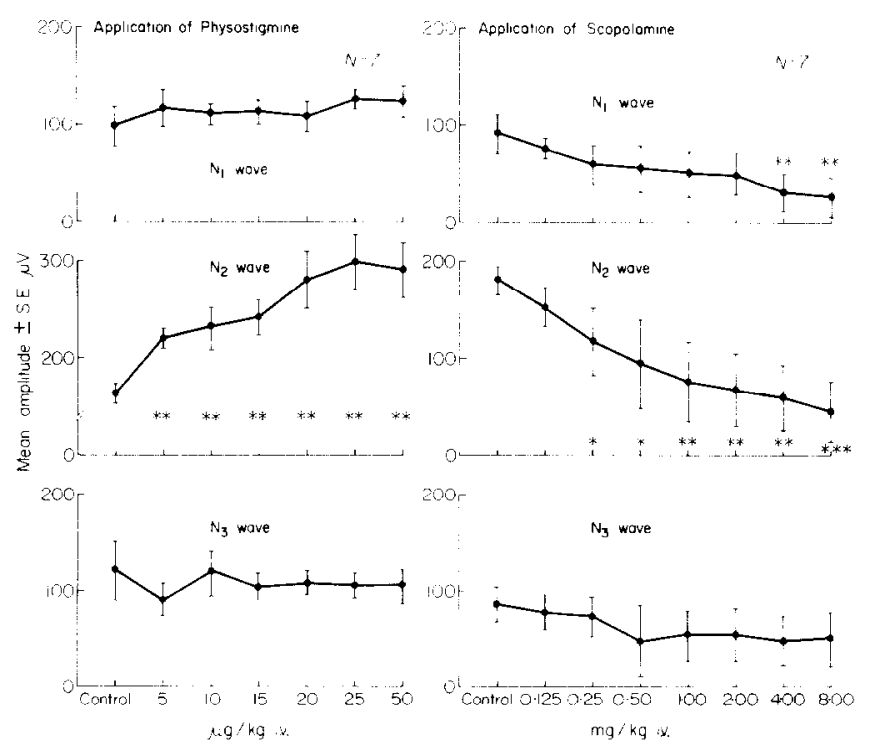

Fig. 3. Accumulative dose effect curves of the action of physostigmine and scopolamine on nucleus vestibularis lateralis tield potentials. Drugs were admmistered intravenously in an aceumulative dose fashion every 5 min. Note the dramatic effects of physostigmine and scopolamine on the $N_{2}$ wave in particular. Very large doses of scopolamine depress the $N_{1}$ potential, suggesting a possible presynaptic influenee. Probability as in Figure? 


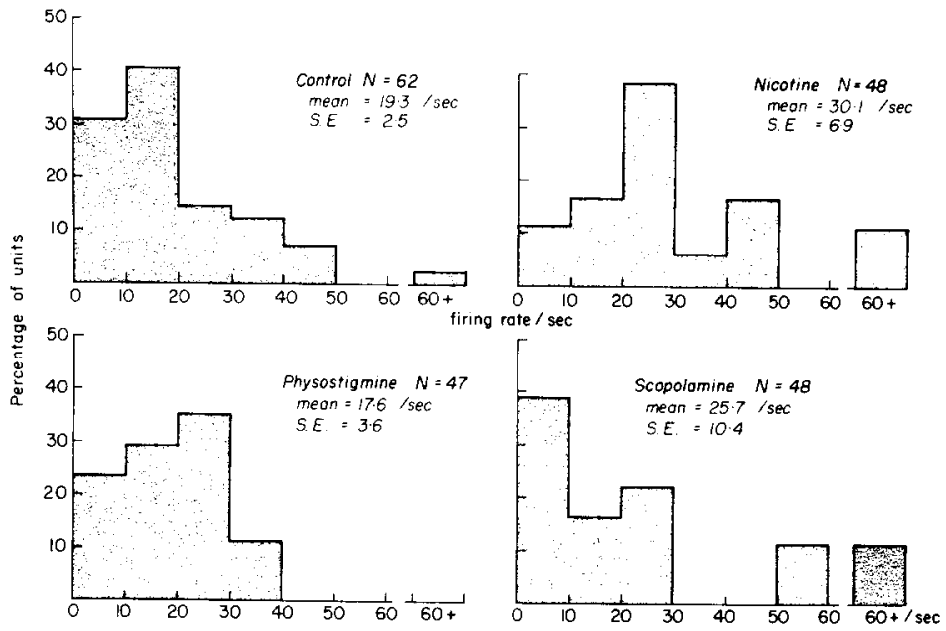

Fig. 4. Modification of the mean firing rate of nucleus vestibularis lateralis neurones following various cholinergic drugs. Note that scopolamine and nicotine tended to produce a bimodal distribution of neuronal firing.

\section{Spontaneous unitary responses of $N V L$}

The spontaneous unitary discharges from NVL were recorded mainly as biphasic but sometimes as monophasic spikes. The majority of units in NVL were $0.5-1.5 \mathrm{mV}$ in amplitude which discharged at a rate of $0 \cdot 1-80 \mathrm{H} z$. The mean \pm S.E. firing rate of 62 units was $19 \cdot 3 \pm 2 \cdot 5 / \mathrm{sec}$, as illustrated in the bar graph in Figure 4 . This value is slightly lower than in other studies (MATSUOKA. 1967. 1969). Nicotine $(25 \mu \mathrm{g} / \mathrm{kg}$ i.v.) and scopolamine $(0.5 \mathrm{mg} /$ $\mathrm{kg}$ i.v.) caused slightly greater spontaneous discharge rates. Physostigmine ( $25 \mu \mathrm{g} / \mathrm{kg}$ i.v.) did not change the distribution of spontancous discharge.

\section{Response of NVL neurones to le'stibular nerte stimulation}

Trains of stimuli of $40 \mathrm{msec}$ duration. $0 \cdot 05-0 \cdot 1 \mathrm{msec}$ pulses at 50,150 and $250 \mathrm{~Hz}$ were applied to the ipsilateral vestibular nerve. Optimal responses in NVL units were obtained at $250 \mathrm{~Hz}$. This frequency also produced excellent unit responses to RF stimulation. Thirty-eight neurones were studicd which responded to ipsilateral vestibular nerve stimulation. Twenty-two NVL neurones excited by vestibular nerve stimulation were further stimulated by physostigmine $(25 \mu \mathrm{g} / \mathrm{kg}$ i.v.). The excitant effects of physostigmine were antagonized by scopolamine $(0.5 \mathrm{mg} / \mathrm{kg}$ i.v.), as shown in Figure 5. The discharge rate of

Control

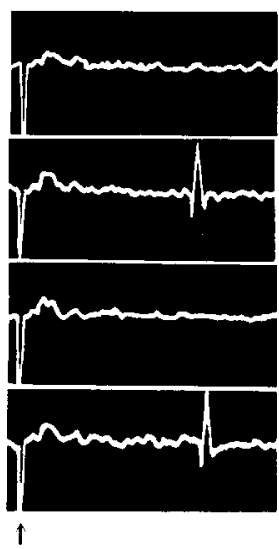

Physostigmine

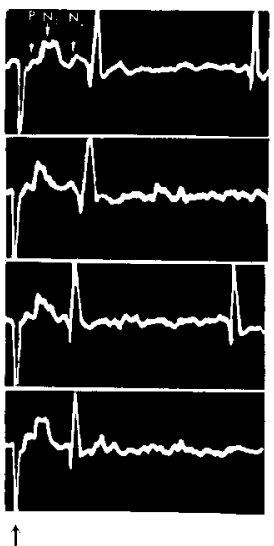

Scopolamine

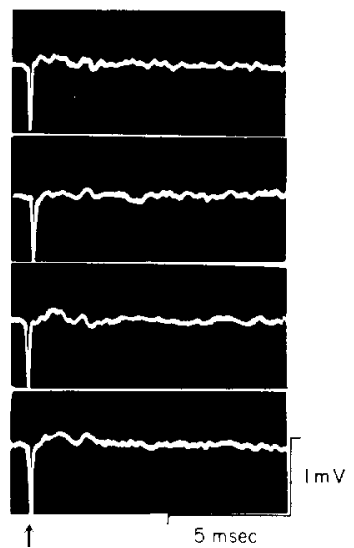

Fig. 5. Effects of physostigmine and seopolimine on unit discharge of nucleus vestibularis lateralis neurones. The ipsilateral vestibular nerve wats stimulated with single shocks of $0.05 \mathrm{msec}$ duration and $2.5 \mathrm{~V}$. Negativity is upward. Time base and voltage calibration are as illustrated. Note that physostigmine tends to ficcilitate single unit discharge while scopolamine depressed it. 


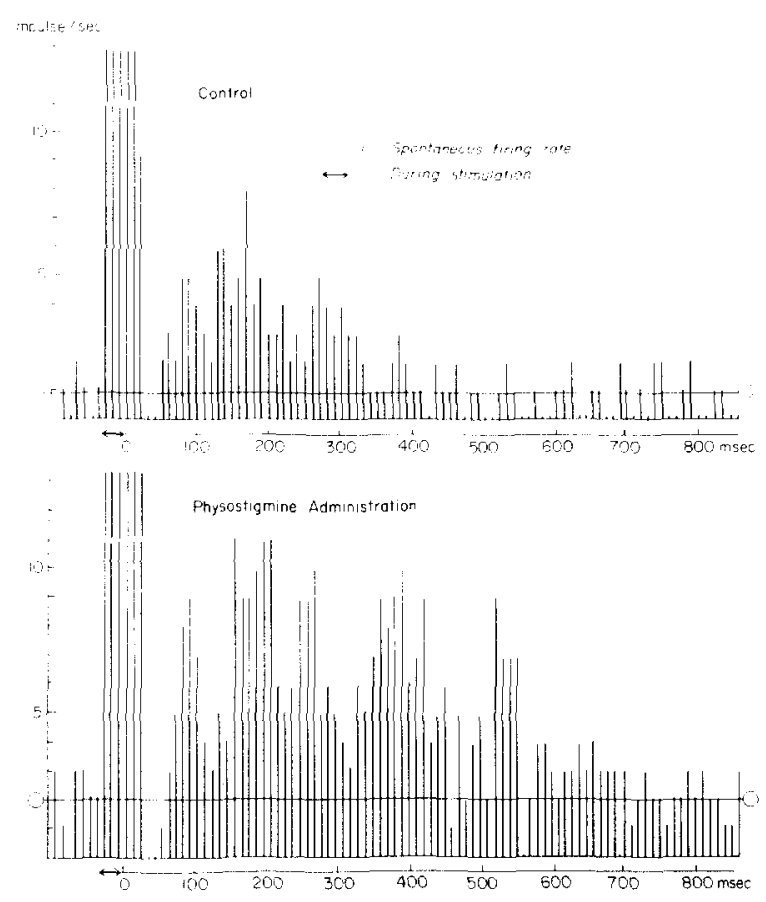

Fig. 6. Post-stimulus time hislogram of responses of single nucleus vestibularis lateralis neurones to ipsilateral vestibular nerve stimulation before and after physostigmine. Note the enhanced effects following physostigmine in an intravenous dose of $25 \mu \mathrm{g} / \mathrm{kg}$. The vestibular nerve was stimulated with a $40 \mathrm{msec}$ train of stimuli $0.1 \mathrm{msec}$ pulses, $3.0 \mathrm{~V} .250 \mathrm{~Hz}$. Each ordinate represents $10 \mathrm{msec}$ and is the mean of 30 stimuli.

these neurones was not changed by nicotine $(25 \mu \mathrm{g} / \mathrm{kg}$ i.v. $)$. The discharge rate of five NVL. neurones excited by vestibular nerve stimulation was depressed by physostigmine and enhanced by scopolamine. Four of these units were not affected by nicotine. Twenty-seven neurones excited by vestibular nerve stimulation did not change their rate of discharge following nicotine. Three neurones excited by vestibular nerve stimulation but not enhanced by physostigmine showed enhanced discharges following $(+)$-amphetamine in intra venous doses of $0.5 \mathrm{mg} / \mathrm{kg}$. Two NVL units excited by physostigmine were unaffected by L-DOPA ( $10 \mathrm{mg} / \mathrm{kg}$ i.v.). Only three neurones inhibited by vestibular nerve stimulation were stimulated by nicotine $(25 \mu \mathrm{g} / \mathrm{kg}$ i.v.). The effects of nicotine were completely antagonized by $2.0 \mathrm{mg} / \mathrm{kg}$ mecamylamine given intravenously (see Table 2). In view of the fact that nicotine caused a reduction of the $N_{2}$ potential, these three NVL neurones might be inhibitory. Trains of stimuli to the vestibular nerve were always more effective than single shocks. Normally short trains of stimuli produced effects lasting about $200 \mathrm{msec}$. After physostigmine, these effects were markedly prolonged (about $500-600 \mathrm{msec}$ ), as illustrated in Figure 6.

Table 2. Nucleus vestibularis lateralis unit responses to vestibular nerve stimulation

\begin{tabular}{|c|c|c|c|c|c|c|c|c|}
\hline $\begin{array}{l}\text { Control } \\
\text { response } \\
\text { lo vestibular } \\
\text { stimulation }\end{array}$ & $\begin{array}{c}\text { Physostignine } \\
25 \mathrm{fg} / \mathrm{kg}\end{array}$ & $\begin{array}{c}\text { Scopolamine } \\
0.5 \mathrm{mg} / \mathrm{kg}\end{array}$ & $\begin{array}{l}\text { Nicotille } \\
25 \Leftrightarrow k !\end{array}$ & $\begin{array}{c}\text { Mecamylamine } \\
2.0 \mathrm{mg} \mathrm{kg}\end{array}$ & $\begin{array}{c}\text { Trimethidinium } \\
1.0 \mathrm{mg} / \mathrm{kg}\end{array}$ & $\begin{array}{l}\text { 1.-DOPA } \\
100 \mathrm{mg} / \mathrm{kg}\end{array}$ & $\begin{array}{c}1+1-A m p h e t a m i n c \\
0.5 \mathrm{mg} k g\end{array}$ & $\begin{array}{c}\text { Yumbers } \\
\text { which } \\
\text { white }\end{array}$ \\
\hline \multirow{8}{*}{ recitced } & Enhanced & Depressed & No change & & & & & 214 \\
\hline & Depressed & Erhanced & & & & & & 1 \\
\hline & Depressed & Enhunoed & No cluilnge & & & & & t \\
\hline & Vor cinange & No chilnge & & & & & T whatneed & 3 \\
\hline & & & Nudulnge & & & & I nbanced! & $!$ \\
\hline & & & Nor channge. & & $V_{0}$ dhange & & & $=$ \\
\hline & t whanced & & & & & No change & & $=$ \\
\hline & Vor chinge & & & & & Folanced & & $\therefore$ \\
\hline Intrinitust & & & tohanced & Depresied & & & & : \\
\hline
\end{tabular}


Control Nicotine $25 \mu \mathrm{gg} / \mathrm{kg}$ iv

Mecomylamine, $2 \mathrm{mg} / \mathrm{kg}, \mathrm{l.} \mathrm{v}$
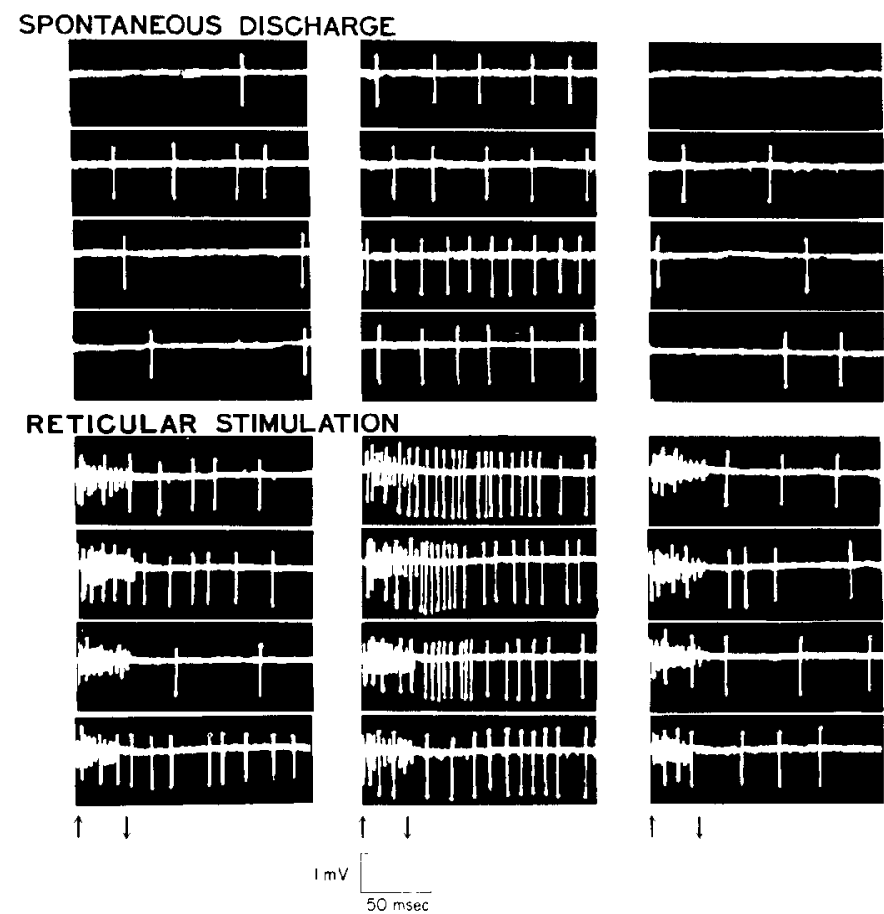

11

Fig. 7. Modification of nucleus vestibularis lateralis neurone discharge to reticular stimulation by nicotine and mecamylamine. Note that nicotine caused a marked facilitating effect in both the spontaneous and evoked rates of unit discharge. These effects were diminished by mecamylamine. Neuronal firing to trains of stimuli to the reticular formation. however. were not greatly affected. Stimulus parameters ats in Figure 6 .

\section{Responses of $N V L$ neurones to RF stimulation}

Thirty-seven NVL neurones were studied before and after RF stimulation. The responses to single RF shocks usually lasted about $10.50 \mathrm{msec}$. Nucleus vestibularis lateralis unit responses to a train of stimuli were always greater and more prolonged than with single stimuli. Sixteen neurones excited by RF stimulation were even further stimulated following physostigmine (25 $\mu \mathrm{g} / \mathrm{kg}$ i.v.). Scopolamine $(0.5 \mathrm{mg} / \mathrm{kg}$ i.v.) did not depress the effects of reticular stimulation. Thirteen units excited by reticular stimulation were further stimulated by $25 \mu \mathrm{g} / \mathrm{kg}$ nicotine. Of these. eight were depressed by physostigmine and five were stimulated by scopolamine. Three were not affected by scopolamine but were enhanced by L-DOPA and or (+)-amphetamine (see Figure 7 and Table 3). Twenty-five neurones excited by RF stimulation were further stimulated by nicotine. Six of these were depressed by mecamylamine $(2.0 \mathrm{mg} / \mathrm{kg}$ i.v.) (see Fig. 8). However. in another six units the effects of nicotine were not altered by pretreatment with trimethidinium $(1.0 \mathrm{mg} / \mathrm{kg}$ i.v.). Only one NVL neurone did not respond to either RF stimulation or the intravenous administration of cholinergic agonists.

Table 3. Nucleus vestibularis lateralis unit responses to RF stimulation

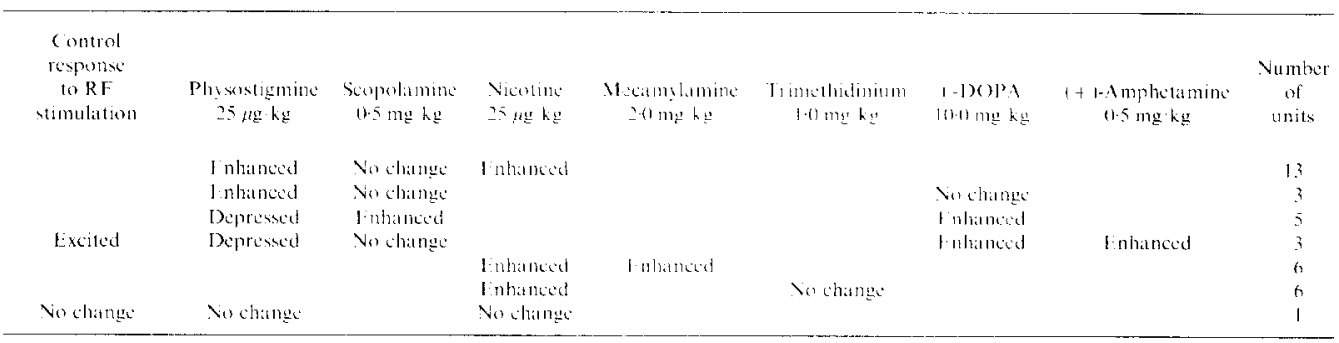


Control

L-DOPA

+ -Amphetamine

SPONTANEOUS ACTIVITY
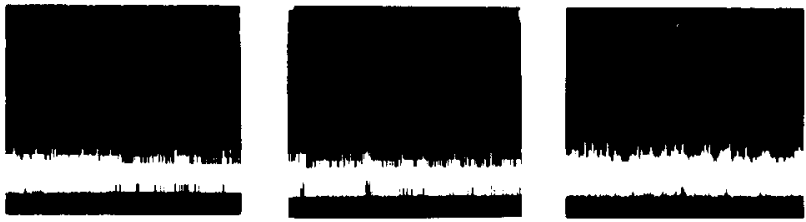

SINGLE RETICULAR STIMULATION

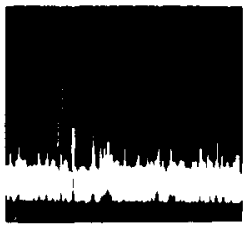

$\uparrow$

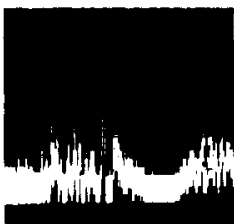

$\uparrow$

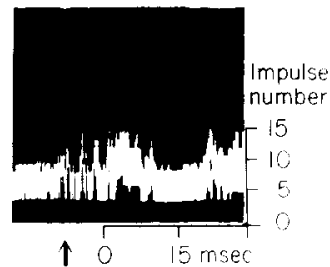

Fig. $x$. Post-stimulus histogram of responses of single meleus vestibularis lateralis nembnes un administration of L-DOPA and $1+$ tamphetamine. The elfects were recorded approvimales 5 min after administration of $10 \mathrm{mg} / \mathrm{kg} \mathrm{I}-\mathrm{DOPA}$ and $1 \mathrm{mg} \mathrm{kg}+$ - -amphetamine, intrakenousli. Vut that 1.-DOPA and $1+$-amphetamine markedy snhanced unit discharge following single reticulin stimuli given at the arroms.

1) $15(1+5 s i d)>$

MiCkLE and ADEs (1954) recorded evoked responses in NVL to ipsilateral vestibulat nerve stimulation. These potentials consisted of irregular waves of 1.01 .25 msec latene? Subsequently. GFrnanist. Iranyi and Livingiston 11959 1 reported similar croked risponses with a latency of less than $1.0 \mathrm{msec}$. More recently. Pricert and SHImaz 119651 : SHmazu and PrIchr $(1965,1966)$ have used microckectrode techniques lor recording fied potentials elicited by ipsilateral vestibular nerve stimulation. They described an initial positive to negative $P$ wate. a large sharp negative $N_{1}$ walve and a delayed negative $r_{2}$ wave. The $P$ wave had a latency of $0.66 \mathrm{msec}$ and was interpreted as indicating the arrival of the afferent presynaptic impulse. The $V_{1}$ wate with a latency of $1.06 \mathrm{msec}$ and a duration of $1.0 \mathrm{msec}$ was attributed to monosynaptically evoled spikes of vestibular neurones. The $N_{2}$ wave which had a latency of 2.4 msce was attributed to polysymaptically evoked spikes. The $P, N_{1}$, and $N_{2}$ waves of Sumize and Priche correspond to our $N_{i}$ $N_{2}$, and $N_{3}$ waves. In our data the $N_{1}$ wave was most often a small negative potential (hence $N$ ) with a mean latency \pm S.E. of $\left(0.50 \pm(0.0) 3\right.$ msee. The $\lambda_{2}$ wave wats a sharp. large negative potential with a mean latency \pm S.F. of $1.09 \pm 0.03$ msec. The $N_{3}$ walle wats at broad negative wave with a mean latency \pm S.F. of $2.41 \pm 0.21 \mathrm{msec}$. These values are almost the same as those of Shimaze and Pricitr. The $N_{1}$ and $N_{3}$ waves were not altered by either cholinergic agonists or antagonists except that a large dose of $4 .() \mathrm{mg} k \mathrm{~kg}$ of scopolamine reduced the $N_{1}$ wave. The $N_{2}$, wave attributed to monosynaptically evoked units was dramatically enhanced by physostigmine and antagonized by scopolamine.

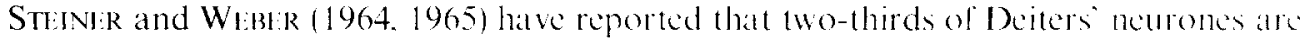

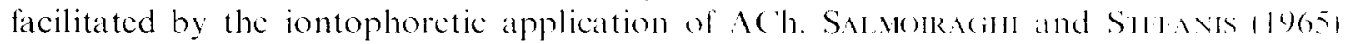
have also reported that Deiters neurones are eonsiscently litcilitaled by both Ac hand notepinephrine (NE). YAMAMOTO (1967) has also reported that NVI. meurones are excited b! iontophoretically applied ACh and NF and depressed by atropine. His data on $A$ C h and atropine agree with our data. i.e. NVL neurones excited by vestibular nerve stimulation were further facilitated by physostigmine and depressed by scopolimine. hut were not stimulated by nicotine. Nucleus vestibulatris lateratis neurones excited by RF stimulation were enhanced in their response by nicotine and blocked by the central and peripherall! acting nicotinic cholinergie antagonist. mecamylamine. Pretreatment w th the peripheralls acting nicotinic cholinergie antagonist. trimethidinium. had no eflect on the neotine ac. sponse. suggesting a central action of nicotine. 
The latency of onset with iontophoretic application of NF to NVL cells takes as long as $60 \mathrm{sec}$ or more (Yамамото, 1967). One would expect a much shorter latency for a chemical transmitter. These findings suggest that NVL neuronal responses to direct application of NE involves slower, perhaps indirect, mechanisms. It should be noted that none of the vestibular nuclei contain many catecholamines (DAHLSTRÖM and FUXE, 1964a, b, 1965: Fix. Fuxi: and Lennerstrand, 1965; Fuxe, 1965).

FILLDBERG and VOGT (1948) measured the rate of ACh synthesis in the isolated vestibular nerve and nucleus. The rate of $\mathrm{ACh}$ synthesis in the vestibular nucleus was higher than in its peripheral nerve (70 $\mu \mathrm{g} / \mathrm{g}$ versus $49 \mu \mathrm{g} / \mathrm{g}$ ). Our own values of 4.30 versus $2.78 \mu \mathrm{mol} / \mathrm{g}$ per hr for ChAc activity are thus qualitatively similar. The distribution of AChE using the histochemical technique of KOELLE (1951) has been described in the vestibular nerve, ganglion of Scarpa. and cells of the vestibular nuclei (LEWIS and SHUTE, 1967; OSEN and RoTH, 1969: SHuTt and LEWIS, 1960). Again our data (Table 1) is in basic agreement. In general, NVL contains more of these enzymes than the vestibular nerve, whether expressed per gram of wet tissue or per gram of protein per millilitre of homogenate.

The amplitude of the NVL presynaptic potential due to vestibular stimulation did not change following physostigmine and scopolamine. It appears that the vestibular nerve is not cholinergic, although it does contain some cholinergic enzymes. According to our pharmacological data, the primary vestibular afferent cannot be cholinergic. The relatively low content of $\mathrm{AChE}$ in the vestibular nerve might be explained by the data of Ross (1969a. b) who observed that the $\Lambda \mathrm{ChE}$ of the vestibular nerve is not in the vestibular primary afferent, but in an autonomic nervous system neurone in Scarpa's ganglion. The major criticism of the present research is that the changes induced by the drugs studied may be reflex in origin and not directly on the vestibular nucleus. Further studies involving the direct application of these agents to NVL neurones is clearly indicated.

\section{REFERENCES}

Botiorlat: J. C.. Bil:Rer, P. and Kalfman, J. (1968). A gold plated platinum tipped, stainless steel microelectrode. Electroticeph. clin. Neurophysiol. 25: 286287.

DAFLSTRÖM. A. and FUXI, K. (1964a). Localization of monoamines in the lower brain stem. Experimentia 20: 398399.

DAHLSTRöm, A. and FUXI, K. (1964b). Evidence for the existence of monoamine-containing neurones in the central nervous system-1: Demonstration of monoamines in the cell bodies of brain stem neurones. Acta physiol. scand. 62: Suppl.. 232, 1 - 55.

DAHLSTRÖM, A. and Fi XK. K. (1965). Evidence for the existence of monoamine neurones in the central nervous system II: Experimentally induced changes in the intraneuronal amine levels of bulbospinal neuron systems. Acta physiol. scand. 64: Suppl., 247. 1-36.

FILLBB:RG, W. and VoGT. M. (1948). Acetylcholine synthesis in different regions of the central nervous system. J. Phisiol., Lond. 107: 372- 381 .

Fix. J., FuXl, K., and LinNiRstrand. G. (1965). Absence of monoamine in olivocochlear fibres in cat. Acta physiol. scand. 64: $259-262$.

Fridorickson. J. M.. SChWARz, D. and Kornhtibr. H. H. (1966). Convergence and interaction of vestibular and deep somatic afferents upon neurones in the vestibular nuclei of the cat. Acta oto-laryng. (Stockh.) 61: 168-188.

FRIEDII: R. L. (1966). Topographic Brain Chemistry, pp. 237 281. Academic Press. New York.

$F_{1}$ xi: K. (1965). Distribution of monoamine terminals in the central nervous system. Acta phisiol. scand. 64: Suppl.. 247,37 85

Grinanits. B. F.. Irayyı. M. and Livingston. R. B. (1959). Vestibular influences on spinal mechanisms. Expl Neurol. 1 : 248.273 .

HuBl., D. H. (1957). Tungsten microelectrode for recording from single units. Science. N.Y. 125: $549-550$.

Kollzi. G. B. (1951). The elimination of enzymatic diffusion artifacts in the histochemical localization of cholinesterases and a survey of their cellular distributions. J. Pharmac. exp. Ther. 103: 153-171.

LI:WIS. P. R. and SHuTI: C. C. D. (1967). The cholinergic limbic system: Projections to hippocampal formation, medial cortex. nuclei of the ascending cholinergic reticular system. and the subfornical organ and supra-optic crest. Brain 90: 521 540.

Lowry, O. H.. Rosibrol gih, N. J., Fark. A. L. and Ranidal.l, R. J. (1951). Protein measurement with the Folin phenol reagent. J. hiol. Chem. 193: 265-275.

MATS:OKA. I. (1967). The responses of single neurone of the vestibular nuclei to caloric stimulation in the cat. Jap. J. Pharmacol 17: 577590 .

MAISt okA, 1. (1969). The responses of a single neurone of the vestibular nuclei to caloric stimulation of ipsilateral and contralateral labyrinth in the cat. Pract. Otol. (K boto) 62: 589598.

MCCAman. R. E. and Hunt. J. M. (1965). Microdetermination of choline acetylase in nervous tissue. $J$. Neturochem. 12: 253259.

Mickl.i. W. A. and Aiss. H. W. (1954). Rostral projection pathway of the vestibular system. Am. J. Physiol. 176: 243246 . 
Osı:N, K. K. and Roтн. K. (1969). Histochemical localization of cholinesterases in the cochlear nuclei of the cat. with notes on the origin of acetyl-cholinesterase-positive afferents and the superior olive. Brain Re's. 16: 165 185.

Precht. W and Shmazi. H. (1965). Functional connections of tonic and kinetic vestibular neurons with primary vestibular afferents. $J$. Neurophysiol. 28: 10141028.

Ross. M. D. (1969a). Orange fluorescence in the acoustic nerve. J. Histochem. Cytochem. 17: 814820.

Ross. M. D. (1969b). The general visceral efferent component of the eight cranial nerve. J. comp. Neurol. 135: 453478.

Salmoiraghi, G. C. and Stifanis, C. N. (1965). Patterns of central neurons responses to suspected transmitters. Archs. ital. Biol. 103: 705724 .

ScHrit:R, B. K. and SCHISTRR. L. (1967). A simplified radiochemical assay for choline acetyltransferase. J. Neuroch'm. 14:977 985.

Shimazi, H. and Pricht. W. (1965). Tonic and kinetic responses of eat sestibular neurones to horizontal angular acceleration. $J$. Neurophysiol. 28 : 9911013.

SHIMAZU. H. and PRECHT, W. (1966). Inhibition of central vestibular neurones from the contralateral labyrinth and its mediating pathway. J. Neturophysiol. 29: 467492.

Scht rt, C. C. D. and Ltwis, P. R. (1960). The salivatory centre in the rat. J. Anat. 94: 59.73

Siakotos, A. N.. Filisi RT. M.. and Histik, R. (1969). A specific radioisolopic assay for acetylcholinesterase and pseudocholinesterase in brain and plasma. Biochem. Med. 3: 1 - 12.

Svidir, R. S. and Nifml:k. W. T. (1961). A Stereotaxic Atlas of the Cat Brain. University of Chicago Press. Chicago. Illinois.

Strivik. F. A. and Weibek, G. (1964). Die Beeinflussung vestibular erregbarer Neurone des Hirnstamms durch elektrophoretisch appliziertes Acetylcholin. Hell phesiol pharmacol Acta. 22: C44 C46.

Sti:INir. F. A. and WriBt:R, G. (1965). Die Becinflussung labyrinthar erregbarer Neurone des Hirnstammes durch Acetylcholin. Helt physiol. pharmacol. Acta 23:82 89.

Yamamoro, C. (1967). Pharmacologic studies of norepinephrine, acetylcholine and related compounds on neurones in Deiters" nucleus and the cerebellum. J. Phamac. exp. Ther. 156: 3947. 